\title{
Assédio moral e reforma trabalhista: entrevista com Margarida Barreto
}

\author{
Edvânia Ângela de Souza ${ }^{1}$ \\ https://orcid.org/0000-0002-8997-7592 \\ ${ }^{1}$ Universidade Estadual Paulista, Faculdade de Ciências Humanas e Sociais, Departamento de Serviço Social, Franca, SP, Brasil.
}

\section{Assédio moral e reforma trabalhista: entrevista com Margarida Barreto}

Resumo: Margarida Barreto é médica e professora na Faculdade de Ciências Médicas da Santa Casa, São Paulo. A entrevistada é uma das precursoras, no Brasil, do estudo sobre assédio moral no trabalho. Nesta entrevista, Margarida Barreto explica o que é o assédio moral, como é o seu processo de reconhecimento e ainda como a reforma trabalhista, efetivada a partir das Leis $\mathrm{n}^{\circ} 13.429 \mathrm{e} \mathrm{n}^{\circ} 13.467$, ambas aprovadas em 2017, pode agravar o contexto propiciador do assédio moral e demais danos à saúde dos trabalhadores e trabalhadoras, com destaque para os desafios postos para os sindicatos de trabalhadores.

Palavras-chave: Assédio Moral no Trabalho. Reforma Trabalhista. Saúde do Trabalhador. Sindicato de Trabalhadores.

\section{Moral harassment and labor reform: interview with Margarida Barreto}

Abstract: Professor Margarida Barreto has a PhD and teaches at the Faculdade de Ciências Médicas da Santa Casa (Santa Casa School of Medical Sciences) São Paulo. The interviewee is one of the pioneers of the study on moral harassment at work. In this interview, Margarida Barreto explains what is moral harassment, how to recognize it, and how the labor reform (Brazilian Law 13429/2017 and Law 13467/2017) may aggravate the problem by enabling a context that favors moral harassment and other harm to workers' health, especially the challenges posed to workers' unions.

Keywords: Moral harassment at work. Labor reform. Occupational health. Worker union.

Recebido em 26.01.2019. Aprovado em 16.04.2019. Revisado em 06.10.2019.

(C) O(s) Autor(es). 2019 Acesso Aberto Esta obra está licenciada sob os termos da Licença Creative Commons Atribuição-NãoComercial 4.0 Internacional (https://creativecommons.org/licenses/by-nc/4.0/deed.pt_BR), que permite copiar, distribuir e reproduzir em qualquer meio, bem como adaptar, transformar e criar a partir deste material, desde que para fins não comerciais e que você forneça o devido crédito aos autores e a fonte, insira um link para a Licença Creative Commons e indique se mudanças foram feitas. 
Edvânia Ângela de Souza: Professora, você poderia abordar os principais elementos que auxiliam na compreensão do assédio moral no trabalho?

Margarida Barreto: O assédio do trabalho, enquanto humilhação, não é algo novo, porém, nesses últimos 20 anos, vem se intensificando ..., eu diria que tem uma relação direta com as mudanças que ocorreram no mundo do trabalho. Hoje, o trabalhador está totalmente voltado para o empenho que lhe é exigido, não somente em relação à jornada de trabalho, mas, atualmente, ele vive em função das metas. Há exigência de metas, independentemente do setor; um professor ou um operário tem que cumprir metas. Essa característica de exigência acentuada da meta, que se dá por meio de uma pressão intensa, uma pressão psicológica, muitas vezes, acontece através de uma gestão por humilhação. Então, quando a gente pensa em assédio moral, a gente está pensando nessas humilhações, que se repetem ao longo da jornada de trabalho e que acometem todo o coletivo daquele setor, daquela empresa, e se relacionam com a organização do trabalho, com a cultura organizacional e outros aspectos. Então, assédio moral, se eu fosse resumir em conceito, são humilhações repetitivas para que você produza mais, para que você alcance a meta. O problema da meta hoje é que ela é fixa? Não, ela não é. A meta é mutável e ela muda inclusive na própria jornada de trabalho, no mesmo dia. Esse aspecto de nunca ser fixa e ir sempre se alternando para mais enlouquece qualquer trabalhador, sobrecarrega qualquer trabalhador e isso é desesperador e quando ele não consegue, aí, vem uma cultura terrível dentro da própria empresa, que o culpabiliza e, muitas vezes, ele internaliza essa culpa e acha que de fato é o responsável por não ter alcançado ou ultrapassado a meta. Em poucas palavras seria isso assédio moral.

Edvânia Ângela de Souza: Você poderia trazer algum exemplo dessa forma de humilhação repetida, algum exemplo que você já acompanhou ou tenha conhecimento?

Margarida Barreto: O assédio moral não é específico das pessoas, muitas vezes, diz assim: “Ah, mas é o pessoal que está na produção, que está no chão da fábrica". Em todo e qualquer nível pode ocorrer essa pressão para produzir mais, vou te dar um exemplo de três engenheiros que começaram a não concordar com algumas situações que estavam acontecendo dentro da empresa, e começaram a criticar publicamente. Eles passaram a ser totalmente isolados dentro da empresa e, por fim, dois deles foram colocados na porta da empresa para anotar as chapas dos carros que passavam na rua, e eles foram. Só para você sentir a intensidade do que é uma pressão, isso quando você depende daquele emprego para sobreviver, para manter sua família, manter seus filhos, então, você se submete. Totalmente arrasados e humilhados não só para si e diante de si, mas diante de todos os colegas. Outro caso: a pessoa não consegue atingir a meta, e isso é bastante comum hoje; a empresa, o gestor que cumpre as políticas da empresa, coloca aqueles trabalhadores para dançar, por exemplo, a dança da boca da garrafinha. Outra coisa muito comum é colocar na mesa daquele trabalhador ou no posto de trabalho, ou se é dentro de um escritório, no seu computador, uma tartaruga, para mostrar o quanto ele não é veloz, o quanto ele não dá produção. Ou seja, os exemplos são infinitos, eu poderia dar outro exemplo, se trata de uma situação que tivemos há muitíssimo pouco tempo em uma grande empresa, a maior vendedora fabricante de bebidas no Brasil, e que levava às seis horas da manhã, para dentro da empresa, em reuniões para motivar, - esse é um discurso que as empresas usam muito, que é a motivação ", levava prostitutas, garotas de programa, para que eles [os trabalhadores] massageassem essas trabalhadoras e ficassem motivados sexualmente ${ }^{1}$. Essa motivação, esse desejo aumentado com a massagem da prostituta, da garota de programa, termina em motivação na linha de produção, ou seja, produzindo mais e mais. Então, os exemplos são infinitos, é vergonhoso a gente pensar que no mundo do trabalho, em pleno século XXI, as empresas no sentido de lucrar cada vez mais, de acumular cada vez mais, lancem mão da humilhação, lancem mão da gestão por estresse, por humilhação ..., para mim, isso passa como um desrespeito total à pessoa humana, uma indignidade em relação à pessoa humana. Para mim, a questão do assédio moral, cada vez que você vai aprofundando, que você vai vendo os casos, você vai ouvindo histórias de trabalhadores, você vai constatando que o que acontece no mundo do trabalho é uma violação constante dos direitos humanos fundamentais. Então, é isso, num quadro muito rápido.

Edvânia Ângela de Souza: Professora, como ocorre o reconhecimento dessa problemática como assédio moral?

Margarida Barreto: No início, é muito difícil perceber, até porque, o assédio, muitas vezes, se dá de uma forma muito sutil, por exemplo, eu culpabilizo você, eu isolo você, eu coloco você separado dos outros para trabalhar, eu aponto as suas dificuldades em relação aos outros que estão dando produção ou eu pego um bastante 
produtivo para mostrar como exemplo, para humilhar o conjunto daquele ambiente de trabalho. Enfim, a pessoa está internalizando: "Eu não dei o máximo de mim, eu poderia ter dado mais de mim”, ou seja, essa política ou essa ideologia da autoculpa, ela é muito intensa dentro das empresas. Então, é difícil o processo, o tempo de cair a ficha, digamos assim, e a pessoa reconhecer: "Estou sendo humilhada", mas também ocorre de naturalizar: "É o direito dele". Escuto muito isso: "ele é nervoso assim mesmo"; "ele sempre chega dentro do setor já gritando" e, muito menos ainda, eu te diria que eles fazem a correlação desse grito do gestor, desse grito do chefe com a forma de organização do trabalho, ou seja, o que é que está por trás disso tudo? A produção mais e mais... Ou seja, mesmo quando se manifesta na relação sociolaboral entre mim e você, tem uma organização que pressiona, tem uma política superior de gestão que pressiona a todos, é quase uma descida constante de pressão em todos os trabalhadores, ainda assim, o reconhecimento fica difícil no primeiro momento.

Vou contar uma história que aconteceu comigo logo que comecei a discutir a questão do assédio moral. Estava eu lá, pelos anos 2000, dentro de um sindicato, auditório cheio e começo a falar, naquele momento, do assédio moral, que era um tema novo, e lá do fim do auditório me grita um homem: "Eu não lhe dei permissão para contar minha história". Eu tomei um susto naquele momento, não conhecia aquele trabalhador, não conhecia aquele homem. E recuperada do susto, continuei falando, quando acabei a fala, tiveram as perguntas e veio aquele homem com umas flores desenhadas no papel e me entregou chorando, aí foi que eu entendi o que de fato tinha acontecido, naquele momento, ele depois me contou que se identificou, por isso, ele me disse: "Eu não lhe dei permissão para falar sobre a minha história". Ele se identificou de uma forma intensa [...], quem sofre o assédio moral não é algo que passa e que esquece, que, "Ah, deixa para lá", é algo que permanece, permanece na alma. A dor é constante e quando este homem ouviu algo que ele sentiu, que ele tinha passado, a sua dor veio intensamente, ele compreendeu que tudo o que ele tinha passado não era culpa dele, era responsabilidade da empresa, da política da empresa. Então, o reconhecimento é assim, às vezes, se dá de forma lenta.

Em relação aos sindicatos houve uma mudança importantíssima no que diz respeito ao reconhecimento, talvez porque quando nós começamos a pesquisa, foi dentro de um sindicato, Sindicato dos Químicos e Plásticos de São Paulo [...], eu tinha certa liberdade de fazer encontros, palestras, trazer a Marie France, uma grande estudiosa do tema na França, enfim, trazer pesquisadores de outros países para a gente discutir aqui no Brasil e dar maior visibilidade a esse tema. Então, os sindicatos eu te direi que, com algumas diferenças de categoria para categoria, têm tido um reconhecimento do assédio moral. O problema é que alguns sindicatos ainda colocam a responsabilidade do acontecido, do assédio moral, entre duas pessoas. A manifestação do assédio se dá entre duas, três, quatro ou em determinado coletivo. Mas o que está na base desse assédio, e nunca se pode esquecer isso, é aquela forma de organizar o trabalho, é aquela forma de distribuir a tarefa, é aquela forma de, a partir da cultura da empresa, tomar uma posição e dizer: "Não vamos repetir assédio moral". Também é comum você ter fofocas, fofocas se repetem ao longo do tempo, fofocas em relação à conduta de uma pessoa, a cor de uma pessoa, a ser gordo ou não ser gordo, enfim, as fofocas mais variadas possíveis em relação àquela pessoa. Então, os sindicatos têm tido uma postura diferenciada, dependendo da categoria uns avançaram mais, outros menos. Têm algumas leis hoje no Brasil, em alguns estados e municípios, em relação ao assédio moral, mas eu sempre brinco dizendo o seguinte: "A lei não anda sozinha, é necessário que haja ação e essa ação tem que ser dos trabalhadores em conjunto, representados pelo movimento sindical e pelo sindicato de origem”.

Edvânia Ângela de Souza: Professora, a terceirização pode afetar ainda mais esse reconhecimento?

Margarida Barreto: Tem uma coisa que me preocupa terrivelmente nos últimos anos, com essa fragmentação que você tem dentro do mundo do trabalho, com essa terceirização e quarteirização, eu diria até que a gente está hoje numa quinteirização, é uma loucura dizer isso, ou seja, você tem uma empresa terceirizada que contrata pessoas para trabalhar em outra, $[. .$.$] hoje, pode ter uma corrente ou uma cadeia de terceirizações.$ Então, por isso, eu digo: o terceirizado quarteiriza e o quarteirizado quinteiriza. Então, é uma linha de montagem fragmentada, vulnerável, sofrida e que envolve milhares de trabalhadores. Então, você ainda não tem uma presença tão intensa como deveria ter dos sindicatos, mas eu te diria que a gente avançou bastante em relação ao combate ao assédio moral. É preciso lei? Sim, por que não? Leis, bastam? Não. É preciso ação? Sim, e não é uma ação individualizada [...] e eu vejo isso muito nos sindicatos pelo Brasil, não é A nem B, [...] ocorre muito de encaminhar o caso para o advogado, e aquele advogado vai para o combate no âmbito da justiça, isso é pouco, é muito pouco. Então, médicos, sindicatos etc. têm que ampliar a questão do campo de luta, senão muito pouco vai se obter no sentido de vitória dos trabalhadores para eliminar, não é para amenizar ou minimizar, mas para erradicar o assédio moral dentro do local de trabalho; para mim a erradicação do assédio moral dentro do ambiente de trabalho está diretamente relacionada com a mudança na organização de trabalho, sem essa mudança na organização do trabalho é quase uma ilusão a gente pensar que de fato vai ter mudança. Agora, há 
uma coisa que é muito simples e nem esse simples a gente tem, ou cada vez a gente tem menos, que é o respeito ao outro. Quando você falou em reconhecimento, você está falando em reconhecimento do trabalhador que sofre e daquilo que ele passou; reconhecimento do sindicato em relação aos seus associados daquilo que está acontecendo dentro daquela empresa; dentro da empresa esse reconhecimento é terrivelmente manipulado em relação à produtividade. Então, há uma coisa que nenhuma empresa no Brasil ou pouquíssimas têm, que é o respeito ao trabalhador e esse é um aspecto muito sofrido, muito dolorido quando você pega um homem ou uma mulher que deu o máximo de si e sequer é reconhecido dentro daquilo que faz.

Edvânia Ângela de Souza: Professora, quando o trabalhador reconhece que está sofrendo assédio moral, como ele consegue comprovar essa violência?

Margarida Barreto: $\mathrm{O}$ trabalhador pode provar, mesmo sendo algo que é subjetivo ao que se manifesta na relação com o outro, algo que está dentro do campo que a gente chama de risco psicossocial, que está na questão da divisão de tarefas, do reconhecimento ou não, da exigência, como eu faço as exigências da meta ou

[...] o assédio moral não é doença, muitos profissionais confundem, às vezes; a gente diz que muitos profissionais orgânicos às empresas atuam no sentido de negar ou diminuir, ou ainda, afastar a compreensão correta do que é o assédio moral. Assédio moral não é doença! Assédio moral é uma forma de administrar, é uma forma de gerir aquela empresa, aquele departamento, aquele conjunto de trabalhadores [...] O assédio moral é uma forma de violência, uma

\section{forma de humilhar o outro} exigindo determinado resultado do seu trabalho. não. Enfim, há uma série de componentes, que podem ser reconhecidos. Mas como é esse reconhecimento? Não tem medição, não é um risco para o qual existe um aparelho para medir sofrimento, assim como não há sofrimentos! Mas o que a gente orienta e que a justiça também tem acordado, é que a pessoa, na medida em que é humilhada pela primeira vez, se a pessoa que a humilhou chega e pede desculpas e não repete, para por aí. Entretanto, se aquele que humilhou, no dia seguinte, nova humilhação, outra humilhação, e essa humilhação se repete no tempo, já não é mais algo acidental da pessoa, da personalidade, do nervosismo daquele chefe. Assim, a pessoa deve anotar cotidianamente aquilo que acontece com ela. Ah, outro aspecto que é importante, é juntar provas. A justiça trabalha com provas, mas como você vai provar aquilo que não é quantificável? Então, além da sua história, você anota, ou você grava, esse diário que você constrói, por exemplo, foi ao médico porque você começou a ficar muito triste, tipo: não dormi direito, pressão alta, isso em consequência do próprio trabalho e das questões que você sofre no trabalho, então, se aquele profissional te deu uma receita, que seja um atestado, tudo isso serve como prova. Então, é todo um processo até você acumular as provas do ponto de vista da justiça, se você tem uma enfermidade que exige a ida ao médico, por exemplo, você percebe que não só não está dormindo direito, mas está ficando muito triste, ou a digestão está ficando prejudicada, se tem tido pensamentos repetitivos e constantes, que, na segunda-feira, só o fato de você pensar que está voltando para empresa teu coração bate aceleradamente, enfim, vários sintomas que podem sugerir sinais do que está acontecendo. Mas se você vai ao médico da empresa, não vamos ter ilusão, na maior parte dos casos, não vai dar absolutamente nada, mas se você vai ao médico do trabalho, que elabora um laudo dizendo que aquilo que você está sentindo tem a ver com a organização do trabalho, tem a ver com o tipo de trabalho que você faz, obviamente que pode a partir daí, estabelecer o nexo causal.

Atualmente, no Brasil, nós temos muitos casos de depressão, cuja origem, cuja causa instalar foi determinada pelo assédio moral, aqui, eu aproveito para dizer o seguinte: o assédio moral não é doença, muitos profissionais confundem, às vezes; a gente diz que muitos profissionais orgânicos às empresas atuam no sentido de negar ou diminuir, ou ainda, afastar a compreensão correta do que 
é o assédio moral. Assédio moral não é doença! Assédio moral é uma forma de administrar, é uma forma de gerir aquela empresa, aquele departamento, aquele conjunto de trabalhadores [...] O assédio moral é uma forma de violência, uma forma de humilhar o outro exigindo determinado resultado do seu trabalho.

Então, você juntando todas essas provas, você já tem o nexo causal, que pode, a partir da patologia que você tem, como uma depressão, emitir uma CAT [Comunicação de Acidente de Trabalho] ou fazer o registro no SINAN [Sistema de Informação de Agravos] [...]. São Paulo, foi o primeiro estado a ter a primeira CAT por depressão, depois foi Recife e, hoje, tem vários casos, infelizmente, de pessoas com transtorno mental em consequência das condições de trabalho, óbvio que houve uma tentativa muito grande de tentar banalizar, naturalizar essas depressões, essas crises de choro, essa insônia e tantos outros sintomas que acometem uma pessoa que é assediada. Então, foi e tem sido uma luta muito grande, constante, cotidiana, para mostrar que toda essa sintomatologia, é fruto da organização do trabalho. Então, se nos anos de 1980, nós tínhamos uma organização do trabalho, que exigia intensamente movimentos repetitivos e/ou era responsável na base pelo surgimento das lesões por esforços repetitivos (LER), hoje, a gente tem uma exigência mental. Você é desempenho. Você é meta. Você só vale, só fica nessa empresa se você produzir, se não produzir, se não vender, tá fora!

Edvânia Ângela de Souza: Você poderia comentar sobre o aumento do sofrimento mental relacionado ao trabalho?

Margarida Barreto: A questão central é a exigência do desempenho. Agora, me diga, como é que a pessoa pode pensar, um homem ou uma mulher, que é arrimo/sustento de família, pode pensar em perder esse emprego, ela se submete, ela aceita, entre aspas, ser sujeitada, humilhada, é quase um processo não consciente, mas de autoproteção, de se alienar de tudo aquilo que está acontecendo com ela. Então, é uma situação bastante complexa, eu ainda diria assim: o grande desafio, que é como esse médico que lida no seu cotidiano com a questão de saúde mental e nós, o professor Lacaz colocou isso claramente ${ }^{2}$, nós temos uma formação, ainda hoje, em pleno século XXI, uma formação positivista, a gente só consegue compreender aquilo que a gente mede, aquilo que a gente palpa, como você vai medir sofrimento e como você vai estabelecer que de fato aquele trabalhador, sem esquecer que existe em nosso meio um discurso muito forte, que o trabalhador finge, que o trabalhador é mentiroso, que o trabalhador é um vagabundo, que o trabalhador está encostando o corpo e que ele não quer trabalhar. Então, como você desfaz essa história, ou seja, tem que virar pelo avesso e trazer a realidade de algo que não é mensurável. Esse é um grande desafio, então, o nosso desafio hoje, é que médicos não só se sensibilizem para discutir a questão da Saúde Mental, mas que também auditores do Ministério do Trabalho e Emprego comecem a pensar em fiscalização da Saúde Mental e de tratamento mental. É possível? Claro, que é possível. É necessário que o médico ou as pessoas que trabalham no campo da saúde, tenham paciência e o respeito para ouvir o trabalhador. Não pode ser em uma consulta de cinco minutos que aquele trabalhador vai me contar a história dele, que eu deduza que de fato aconteceu aquilo que ele está me dizendo, o assédio moral, as violências repetidas. Constado isso, eu posso ir sim à empresa fazer uma vigilância. Como? É possível, eu já fui acompanhando auditora-fiscal, e é possível sim, também não pode ser em meia hora e não pode ser também na presença, ao conversar com os trabalhadores, dos gerentes, tem que ser numa relação com os trabalhadores, em uma sala separadamente, em que cada um, separadamente, conte o que está acontecendo dentro daquela empresa, então você vê que já demanda um tempo muito grande, não é uma fiscalização que você faz em uma só vez, às vezes, será necessário voltar duas, três ou quatro vezes naquele ambiente.

\section{Edvânia Ângela de Souza: São muitos os desafios para essa vigilância?}

Margarida Barreto: Sim, há dificuldade, inclusive das pessoas que estão do lado de fora. Vou te contar outra história que aconteceu comigo. Um desembargador, publicamente, disse assim: "Eu queria pedir desculpas porque toda vez que a Margarida falava da questão do assédio moral, eu achava que ela fantasiava muito, até o dia em que eu peguei um caso de uma empresa $X$, que não só humilhava homens e mulheres publicamente, mas as mulheres que não davam produção, aliás, as mulheres são as mais humilhadas dentro do ambiente de trabalho, eles as ofereciam para programas sexuais para os trabalhadores produtivos". As pessoas não conhecem o que é o mundo do trabalho na sua essência. O mundo do trabalho é objetivo e tem histórias e histórias marcantes. Bem, no caso da situação relatada pelo desembargador, as mulheres que se negavam a sair para fazer programa sexual com os colegas produtivos eram queimadas com cigarro. Então, esse desembargador conta a história publicamente e me pede desculpas publicamente, ele olha para mim e diz que não queria acreditar, mas "Só vinha a Margarida na cabeça dele...". E afirmou o quanto tinha julgado incorretamente por 
não conhecer. E é isso, as pessoas julgam incorretamente, superficialmente, por não conhecer o que é o real, o que é objetivo e o que é que de fato existe no interior das empresas, o discurso é um, todas as empresas falam em sustentabilidade, toda empresa tem uma missão, toda empresa tem valores, e como é que isso se dá na prática cotidiana? Para você ter ideia, em grande parte, eu não estou falando aqui de pequena empresa, aliás, sem nenhum preconceito, mas o meu olhar sempre esteve voltado para as grandes empresas, as multinacionais, que têm o discurso mais forte. Então, muitas trabalhadoras e trabalhadores sequer têm direito a fazer suas necessidades fisiológicas. Eu peguei uma empresa uma vez, que ela colocava dentro do banheiro das mulheres uma câmera ${ }^{3}$. Por que preciso de uma câmera no banheiro? Para vigiar o quê? Quebrando, rompendo, invadindo, por isso, que eu digo, é uma violação constante dos direitos fundamentais da pessoa humana trabalhadora. Então, às vezes, eu penso que esse tipo de empresa, que tem um discurso tão forte, que não cuida dos seus trabalhadores, sequer notifica as doenças visíveis e quantificáveis como as LER/DORT [Doenças Osteomusculares Relacionados ao Trabalho], veja que há uma subnotificação muito grande. Imagina se vai notificar ou se vai aceitar que há notificação das questões de transtorno mental e a tendência maior é não notificar, e culpabilizar a pessoa, e se aquela pessoa chatear muito, demite.

Edvânia Ângela de Souza: No caso do assédio moral, a situação é ainda mais complicada, não é?

Margarida Barreto: Vou te contar um caso de um engenheiro. Só estou contando o caso do pessoal de nível universitário para a gente não achar que isso é bobagem. Um engenheiro de uma terceirizada, que prestava serviço para a Petrobras, começou a observar que os trabalhadores da terceirizada tinham péssimas condições e não recebiam o equivalente e, então, ele, enquanto engenheiro, numa situação melhor do ponto de vista de salário, resolveu tomar as dores dos trabalhadores e lutar. Foi a gota d'água, você não pode ser solidário, você tem que ser solidário com o capital; ele quer você lá à meia-noite, você tem que ir; ele quer você durante doze ou quatorze horas, não interessa, você tem que ir. Trabalhar até às três horas da manhã? Não interessa, e não vai te pagar hora extra, não interessa, você tem que ir e até agradecer esse tão honroso convite de fazer uma jornada prolongada de trabalho. Então, esse trabalhador, engenheiro, foi isolado, eu tenho fotografias desse homem; ele foi colocado e, é terrível a foto, porque ele foi colocado do lado de fora da empresa, chovesse ou fizesse sol no horário de trabalho dele, ele estava sentado e o mais interessante é que aqui estava a cadeira dele e aqui as latas de lixo. Não precisa falar muito o que a empresa estava vendo nesse trabalhador, um lixo, já não prestava mais para a empresa. Não demite, por quê? Não demite, mas força o pedido de demissão, para empresa é muito mais econômico e a empresa visa lucro qualquer que seja ele, é muito mais econômico que o trabalhador peça demissão do que a empresa o demitir. Este homem, quando eu o conheci, ele tinha seis meses nessa situação, todos os dias que ele chegava na empresa, ele ia para o lado de fora da empresa e ficava sentado junto à lata de lixo e até os amigos e, isso é mais dolorido, para qualquer trabalhador que sofre humilhações dentro do trabalho, é ser isolado pelos próprios colegas. E, aí, até você entende porque esse isolamento, é o medo de ser o próximo, não é por ser mau-caráter, mas o próprio capitalismo vai estimulando essa indiferença em relação ao sofrimento do outro, e nessa indiferença, culpabiliza mais o outro que não está dando as condições, não está produzindo, imagina um trabalhador engenheiro se meter com os operários? "Ah, não, isso já é demais". Então, é isso que a empresa não suporta. Se você vier com o chicote batendo, estou falando de uma forma metafórica, nos trabalhadores para que trabalhem mais para aquela empresa, aí, você é até agraciado, você é até homenageado... Olha, eu tenho visto empresas, que o trabalhador não deu produção, empresas grandes, repito mais uma vez, não estou falando de pequenas, então, colocam um caixão de defunto e um boneco dentro daquele caixão com o nome da pessoa que não deu a produção no mês, dá para você imaginar o que significa isso para um trabalhador; é um tipo de humilhação pública ${ }^{4}$. Então, as humilhações são as mais terríveis, as mais desumanas possíveis. Quando você pensa o que fazer, tem muito por fazer, fundamentalmente os sindicatos, a gente sempre orienta, até hoje, que o trabalhador procure seu sindicato. Procure seu sindicato para denunciar, mas a gente vê que tem uma falha aí, porque o sindicato passa para o advogado e não se envolve, não vai ao Ministério do Trabalho e Emprego ou no CEREST [Centros de Referências Especializados em Saúde do Trabalhador] exigir uma vigilância dentro daquela empresa, levantar as condições de trabalho e levantar como é a gestão dentro daquela empresa, qual é a cultura da empresa ante a questão do assédio. Então há muito por que fazer.

Edvânia Ângela de Souza: Professora, com a denominada (d)reforma trabalhista, você acredita que ocorrerá um agravamento da organização do trabalho do ponto de vista das garantias fundamentais da pessoa humana trabalhadora? 
Margarida Barreto: Intensificação das práticas de assédio, eu não vejo de outra forma, porque um trabalhador contratado por horas não é reconhecido formalmente enquanto trabalhador. Há uma fragmentação, esse tipo de contrato exige a permanência do trabalhador na empresa apenas enquanto a empresa exigir, ele não pode dizer "não". Eu não posso considerar que isso são condições dignas e estou colocando muito superficialmente o que acontece. E, então, a Reforma ou a Deforma Trabalhista, vai deformar mais, mais e mais as relações pessoais e sociolaborais dentro do ambiente de trabalho. Se hoje, você já tem uma política de isolamento, uma política de fazer com que você não tenha ou não crie laços de amizade; não crie laços fraternos com o outro, não dê ajuda mútua a um colega teu que possa estar com dificuldades, você não pode ajudar, imagina numa situação de terceirização, que você não tem nenhum vínculo como a empresa a não ser este de trabalhar e trabalhar, então, como você pode ser solidário? Como você vai perder tempo para ensinar algo ao outro, que é recém contratado na empresa, "ele, que se vire, como eu estou me virando". [...] Ou seja, a fragmentação com essa deforma [trabalhista] leva também a um isolamento acentuado entre os trabalhadores, a um distanciamento muito grande entre os trabalhadores, uma alienação acentuada entre os trabalhadores e de si também; ele não tem nem tempo para saber o que é que ele está fazendo, o que que está fazendo e para onde vai, que finalidade tem. Ele tem uma preocupação, aquele dinheiro que ele vai receber como uberizado, qualquer que seja, lembrando que hoje, a gente já tem um crescimento grande de uberizados com nível universitário, acho que em torno de mais de 4\%. Isso é algo para a gente pensar, se quando vocês pegarem Uber, por exemplo, pergunte qual é a profissão do motorista e vocês vão ter surpresas. Então, isso vai se acentuar, essa fragmentação, essa desregulamentação porque não acontece só nas relações de trabalho, isso acontece na minha vida, afeta minha vida e afeta a vida da minha família. Como eu trabalho e só recebo aquelas horas que trabalhei...

\section{Edvânia Ângela de Souza: e o trabalho intermitente?}

Margarida Barreto: Certa vez, encontrei um trabalhador, isso tem uns quatro anos, na Inglaterra, um jovem com seus 23 anos, ele trabalhava numa empresa e foi demitido e ele me mostrou o celular dele, eu fiquei impactada, ali, estava uma escala que ele recebia semanalmente de uma determinada empresa das horas que ele iria trabalhar e ele só ganhava aquelas horas que ele trabalhava. Ele não tinha nenhum vínculo a não ser esse. E eu disse assim: "mas não dá para você arranjar outro trabalho?" Não, disse ele, porque se coincidisse com os horários ele perderia aquela empresa. Então veja, você fica escravo, você fíca preso àquela empresa pelo mínimo que ela vai te pagar, mas você fica preso, porque você tem dívidas, você tem que comer, pagar luz, pagar aluguel; então, é um escravo diferente. Um escravo endividado que nada recebe para sobreviver, ou recebe o mínimo. Então é perverso, e o mais triste desse momento atual, que eu percebo dentro das empresas, é o cinismo, mas não apenas das empresas, mas da área governamental também; há um cinismo em dizer que vai ter mais emprego. Que tipo de emprego? Vulneráveis e de péssima qualidade. Qual é a proposta? É matar os trabalhadores! É essa proposta, no fim, que está colocada, de forma sutil, sem armas, não preciso armas para matar, eu mato de fome e não precisa muito se a gente olhar o que é hoje, o prof. Lacaz colocou a questão do número de desempregados hoje, que a gente no Brasil, que aumentou acentuadamente nesses últimos dois anos, a gente tem praticamente quatro Uruguais de desempregados.... Se você der uma voltinha em São Paulo (capital) você vai ficar assustada, revoltada..., é um misto de tristeza, quando você passa, por exemplo, no Minhocão, na Paulista, na 14 Bis e tantos outros lugares, e se você tiver um pouquinho de paciência de parar, sem medo nenhum, porque são trabalhadores que ali estão, e conversar com aqueles trabalhadores um pouquinho e eles confiarem em você para ouvir as histórias deles, você vai ver que tem $4 \%$ dos moradores de rua, hoje, em São Paulo, com nível universitário ${ }^{5}$, quando você olha esse pessoal que está na rua, a maior parte são homens. Há discursos que eles são vagabundos. São vagabundos? ${ }^{6}$ É, na verdade, o resultado de uma fragmentação dentro das relações de trabalho, resultado de uma mudança na legislação. Ok, você arranja emprego, esse é o discurso do governo federal é que a reforma trabalhista vai aumentar oferta de emprego. Mas que tipo de emprego? Com que salário? Como essas pessoas vão manter uma vida digna? A gente pode falar em dignidade? O que é dignidade afinal? Então, são perguntas que a gente tem que se fazer para que possa compreender o que as mudanças na legislação trabalhista oferecem, a quem elas vêm favorecer? Eu posso dizer que para mim, em nenhum momento, elas favorecem os trabalhadores. Para mim, toda essa fragmentação, todas essas mudanças na lei favorecem ao grande capital, favorecem ao sistema financeiro, se você tem [condições] é bem-vindo, se você não tem, por favor, desapareça, se não for um desaparecimento pela morte é por incompetência sua. Você não deu o máximo que deveria ter dado, esse é o discurso. Esse é o discurso, e desvendar, desfazer, tirar a roupa desse discurso é fundamental para a gente pensar em soluções conjuntas para mudar essa situação. Nada é eterno, a história está cheia de exemplos, pode haver mudanças, as mudanças não são 
espontâneas, muito menos, por ordem do divino espírito santo, elas precisam da ação humana, da ação do homem..., É a ação dos trabalhadores como um todo, pensando e tentando uma sociedade fraterna e justa em que o emprego seja de fato emprego digno e não uma forma de maltratar e fazer o indivíduo sofrer.

Edvânia Ângela de Souza: Gostaria que a Professora comentasse as afirmações do presidente do Tribunal Superior do Trabalho, Ives Granda, que em debate no Senado ${ }^{7}$, no momento em que se discutiu a Reforma Trabalhista (ou Deforma Trabalhista) e a respeito das multas por danos extrapatrimoniais, afirmou que o trabalhador não poderia receber um valor alto de indenização, para não ter vantagem sobre o ocorrido. Como você avalia isso?

Margarida Barreto: O objetivo é fortalecer o capital, cada vez mais, e não é à toa também, que entre 2016 e 2017, houve um aumento acentuado em termos de diminuição de ganhos e uma diminuição dos novos ricos. Ou seja, cada vez mais, a gente tem menos pessoas bilionárias, só para você ter uma ideia, no planeta hoje, oito grandes bilionários têm a riqueza de cem milhões de pessoas e se você aumentar para $1 \%$, então esses dados são totalmente extravagantes e extrapolam qualquer raciocínio lógico, né?? ${ }^{8}$. Então, todas essas mudanças na legislação trabalhista favorecem ao grande capital... Quero relatar um caso de uma trabalhadora, que entrou com processo na justiça depois de ter sofrido assédio moral intenso, durante mais de dois anos e, na conclusão final, ela recebeu R \$ 1.000,00 (mil reais), dividido em duas vezes. A dor do pobre tem um preço, um ministro se é humilhado e tivemos um exemplo recente, daí, a vida tem outro preço. Aqui, também é uma questão de classe social. Você não vale nada se você é um trabalhador da base, mas se você é um grande capitalista, você merece sim ser reconhecido pelo que foi lesado ou no que sua moral foi danificada.... Então, essa trabalhadora que recebeu R $\$ 1.000,00$, em duas vezes, para mim, ela sofreu uma nova humilhação, de onde, da empresa? Não, mas do próprio sistema e através do sistema. Mas que sistema? O sistema judiciário, a própria lei, a própria legislação, não uma legislação em si, ela não tem vida sozinha, mas os próprios legisladores humilharam mais uma vez essa mulher. Quando eu atendi essa trabalhadora, ela conta essa história, falou o quanto estava se sentindo acabada e ela disse assim: "eu me sinto humilhada, mil vezes eu não tivesse entrado, porque eu fiquei marcada", é verdade, $\mathrm{R} \$ 1.000,00$ (mil reais)! A honra não tem preço. A ética não tem preço. A dignidade de uma pessoa não tem preço. Então, você balizar o pagamento pelo salário, pela classe social, óbvio quem ganha $\mathrm{R} \$ 900,00$ (novecentos reais) é a empregada doméstica, quem ganha 200 mil por mês, há quem ganha 200 mil por mês... Então, você balizar o ganho ou o que uma empresa deve pagar como se aquele sofrimento fosse diferente de um alto executivo, é de uma maldade, é de um cinismo, é de uma indiferença à dor do outro, é uma banalização. Eu, digo que a gente está na barbárie, ou caminhando para ela, porque nós naturalizamos a violência e, aí, barbariza as relações. Isso é capitalismo, mas isso é capitalismo em que momento dele? O momento mais cruel, eu não sou especialista nisso, então, talvez esteja dizendo uma bobagem, mas é o capitalismo financeirista, no que você tem dinheiro, ótimo, mas se você não tem, está fora, para que você vai ganhar dinheiro, para desperdiçar? [...] então, até no valor existe a questão de classe aí colocada. Quem ganha com toda mudança é o capital e fortalece esse pequeno grupo que comanda o planeta, não é nem o Brasil, é o planeta. Então, não dá para a gente concordar.

Edvânia Ângela de Souza: Eu gostaria que você comentasse, como você analisa a organização coletiva dos trabalhadores e trabalhadoras e o fortalecimento dos sindicatos e para o enfrentamento desse estado de coisa.

Margarida Barreto: Olha, "caminhante, não há caminho, o caminho se faz ao caminhar", dizendo isso, quero dizer que o desafio é muito grande para os sindicatos como um todo, mesmo aqueles que avançaram um pouquinho mais na discussão do assédio moral no trabalho, o grande desafio, é organizar. Isso se perdeu no meio do caminho, essa capacidade de entrar em contato com a base, se perdeu no meio do caminho, essa escuta da base, compreender a base, infelizmente, muitos dirigentes sindicais no Brasil inteiro e não só, até na América Latina, e isso também não foi a toa, tem também um dedo do grande capital...; há também os que envelheceram e continuam sendo dirigentes sindicais, não estou falando que ao envelhecer, eles não devessem participar. Não é isso, mas eu estou falando que a responsabilidade seria maior na formação das pessoas, que estariam em contato com a base e a base não quer o sindicato só nas festinhas. A base quer o sindicato mais próximo. Quantas vezes, eu ouvia: “Ah, eu já procurei o sindicato e eles disseram que é bobagem..." A base não quer isso. [...] base procura ser escutada minimamente e quer também que esse sindicato diga: "ó eu estou 
com você, nós vamos brigar"; quando você transfere a responsabilidade ou para o médico ou para o advogado, você abriu mão. Como é que você vai formar pessoas em festas, só em festas? Como é que você vai formar pessoas só em grandes palestras em que escolhe um tema legal, mas eu não estou falando dessa formação, mas da formação que é cotidiana, é onde trabalhador mora também.

Quando você tem essa fragmentação dos trabalhadores, como é a terceirização, que cria uma rotatividade, por exemplo, hoje, ele está no setor plástico, amanhã, no setor calçadista, depois de amanhã, na costura, enfim, ele não tem o sindicato; não existe sindicato terceirizado, acho que logo vai surgir. Mas, não existe sindicato para terceirizado. Como é que você vai organizar? Então, eu creio que o desafio é muito grande...

Mas, acho que a gente tem sempre que manter a esperança, mas não a esperança no sentido de esperar, mas a esperança ativa, a esperança de ir onde me querem, a esperança de ir lá onde estão querendo ver alguma coisa diferente, onde estão querendo também ter uma esperança de mudança, porque não tem felicidade em alguém que vê seu filho chorando com fome e dizer: "Ah, Deus vai me ajudar e quem sabe daqui um ano eu tenho alguma coisa.".

$\mathrm{Eu}$, às vezes, vejo com muita preocupação um fenômeno que está acontecendo de forma quase sutil, mas muito firmemente nas periferias, fundamentalmente, em São Paulo, não sei nas cidades do interior, nos municípios, mas na capital, principalmente, nas periferias, na zona sul e na zona leste, mas mais zona norte, o envolvimento de facções e a oferta de pequenos trabalhos, como venda de drogas e, por outro lado, tem outra realidade hoje totalmente distinta dessa, de pessoas com nível universitário e alto executivo que para aguentar o ritmo da empresa, também vai para a droga. Que isso? Que mundo é esse? Então, não estou culpando que a só a ausência do sindicato, mas ele tem que estar mais presente, tem que mudar a forma de fazer política, tem que se comprometer. Se você perguntar de novo eu vou dizer: "Caminhante, não há caminho, o caminho se faz ao caminhar", não tem receita para isso, não conheço". Acho que o desafio para cada um de nós é muito grande, muito intenso e deve ser bastante comprometido, nós não somos mais crianças... E, no entanto, a gente continua com vigor para continuar combatendo, denunciando e resistindo à todas essas práticas, que vem destruindo essa relação dos trabalhadores com eles mesmos, dos trabalhadores com a sua família. [...] e só vem acentuando uma relação totalmente distinta, dicotomizada, que é a relação capital e trabalho, mesmo quando ele é chamado de "colaborador", ele nunca foi colaborador, só se ele colabora com a própria exploração sem saber que está sendo colaborador da própria exploração. Então há que lutar, o desafio é muito grande, há que se organizar, Há que dar formação a essas pessoas.

Então, para finalizar, quero deixar um poema, um poema para os trabalhadores de todos os setores, é um poema do Mario Quintana, é uma estrofe, eu acredito que a poesia, nesses momentos de dores, de sofrimento e de tristeza, nos dá certo otimismo para continuar esperançando, continuar andando, continuar fazendo... a, estrofe dele diz:

Se as coisas são inatingíveis... ora! Não é motivo para não querê-las...

Que tristes os caminhos, se não fora

A presença distante das estrelas! (Mario Quintana, Das utopias, 1951).

\section{Referências}

AGÊNCIA SENADO. Presidente do TST e procurador-geral do Trabalho divergem sobre reforma. Agência Senado, 10, mai., 2017. Disponível em: https://www12.senado.leg.br/noticias/materias/2017/05/10/presidente-do-tst-e-procurador-geral-do-trabalho-divergemsobre-reforma. Acesso em: 07 out. 2019.

AMBEV é multada por constranger funcionário com pornô e prostitutas: de acordo com colaborador, que se sentiu "constrangido" por ser casado e evangélico, havia até "vale garota de programa" para incentivar cumprimento de metas. Época Negócios, [S. l.], 03 set. 2012. Disponível em: https://epocanegocios.globo.com/Informacao/Dilemas/noticia/2012/09/ambev-tera-de-pagar-r-50-mil-funcionario-porlevar-prostitutas-reunioes.html. Acesso em: Acesso em: 20, set., 2018.

BORGES, F. Juíza condena frigorífico de MT por câmeras no banheiro. GD Gazeta Digital, [S. l.], 24 maio 2013. Disponível em: http:/ /www2.gazetadigital.com.br/conteudo/show/secao/9/og/1/materia/379136/t/juiza-condena-frigorifico-de-mt-p. Acesso em: 5 jan. 2019. EVANGÉLICO ganha indenizações da Ambev após festas com prostitutas. Folha de São Paulo, São Paulo, 03 set. 2012. Disponível em: http://classificados.folha.uol.com.br/empregos/1147719-evangelico-ganha-indenizacao-da-ambev-apos-festas-com-prostitutas.shtml. Acesso em: 08 out. 2019.

EVANS, S. Gigante do setor de seguros promoveu orgia para funcionários. BBC News, Berlim, 20 maio 2011. Disponível em: https:// www.bbc.com/portuguese/noticias/2011/05/110519_alemanha_seguros_orgia_rp. Acesso em: 20 set. 2018. 
LEX MAGISTER. Danos morais: empresa que instalou câmera no banheiro dos empregados é condenada a indenizar. Lex Magister, Porto Alegre, [2019]. Disponível em: http://lex.com.br/noticia_26214027_DANOS_MORAIS_EMPRESA_QUE_INSTALOU_CAME RA_NO_BANHEIRO_DOS_EMPREGADOS_E_CONDENADA_A_INDENIZAR.aspx. Acesso em: 15 jan. 2019.

SÃO PAULO. Tribunal Regional do Trabalho (2. Região). Processo TRT/SP n. ${ }^{\circ}$ 0002818-52.2013.5.02.0077. 77 ${ }^{\mathrm{a}}$ Vara do Trabalho de São Paulo. Recorrente: Carrefour Comércio E Indústria Ltda. Recorrido: Lucélia da Silva. São Paulo, 11 nov. 2014. Disponível em: https://www.conjur.com.br/dl/trt-decisao-caixao.pdf. Acesso em: 25 nov. 2018.

SEIS BRASILEIROS têm a mesma riqueza que os 100 milhões mais pobres. Carta Capital, [S. 1.], 25 set. 2017. Disponível em: https:/ /www.cartacapital.com.br/economia/seis-brasileiros-tem-a-mesma-riqueza-que-os-100-milhoes-mais-pobres. Acesso: em : 20 set. 2018. VILARDAGA, V. De advogado a professor, diplomados viram moradores de rua em São Paulo. Folha de São Paulo, São Paulo, 8 out. 2017. Disponível em: https://www1.folha.uol.com.br/cotidiano/2017/10/1925287-de-advogado-a-professor-diplomados-virammoradores-de-rua-em-sao-paulo.shtml. Acesso em: 20 set. 2018.

\section{Notas}

1 Sobre o constrangimento citado pela Prof. ${ }^{\text {a }}$ Margarida registra-se que a Ambev foi multada por constranger funcionários com pornô e prostitutas (AMBEV..., 2012). Interessante observar que segundo a Folha de São Paulo(EVANGÉLICO..., 2012), a empresa alegou “"[...] que o constrangimento não era de natureza "tipicamente trabalhista" e que teria prescrito", mas que "O juiz, relator do processo, ministro Brito Pereira [...]" não teria concordado. Além da empresa brasileira, anteriormente já havia sido noticiado situação semelhante com a empresa Ergo, uma das subdivisões da Munich Re, que em 2007, promoveu uma festa para os seus melhores representantes de vendas. A festa foi realizada em uma estação de águas termais na capital da Hungria, Budapeste, quando "vinte prostitutas foram contratadas para a festa, que teve cem convidados" (EVANS, 2011).

2 Referência à entrevista “O campo Saúde do Trabalhador e a Reforma Trabalhista: com Francisco Antonio de Castro Lacaz" realizada no mesmo dia da entrevista com a Profa. Margarida, no dia 20 de setembro de 2018, na Unesp-Franca, SP. A entrevista está disponível em: https:// www.youtube.com/watch?v=Guh_L9c9ppE\&feature=youtu.be. Acesso em: 07 out. 2019.

3 Infelizmente, na Internet, é possível encontrar a menção a processos trabalhistas que cobram ação na justiça contra a vigilância praticada pelas empresas por meio de instalação de câmeras em banheiros, a exemplo, ver Lex Magister ([2019]) e Borges (2013).

4 Tal exemplo citado pela Professora encontra correspondência com a situação julgada pela $77^{a}$ Vara do Trabalho de São Paulo, conforme se lê no processo TRT/SPN..$^{\circ}$ 0002818-52.2013.5.02.0077, disponível em meio eletrônico: Aduz a recorrente que, em meados de 2009, visando incentivar seus funcionários, foi lançada uma campanha motivacional que tinha como escopo demonstrar a necessidade dos trabalhadores se renovarem. Para tanto, foi utilizada uma caixa de papelão "simbolizando um caixão", e um cartaz "onde se informava o falecimento da pessoa que impedia o crescimento profissional na empresa". Menciona, ainda, que "não há como se falar que ao olhar para o mesmo e ver sua imagem refletida, a recorrida ou qualquer outra pessoa pudesse ter a real impressão de que estivesse dentro de um caixão, sendo velada. Pela foto acostada aos autos se observa o espelho do lado de fora da caixa". (SÃO PAULO, 2014).

5 "Entre 2010 e 2015, houve um crescimento do número de pessoas formadas em universidades vivendo em situação de rua, tanto na população acolhida em albergues quanto na que dorme nas calçadas, 1,9\% para 4\%." (VILARDAGA, 2017).

6 "Diferentemente do que se costuma imaginar, a maior parte dessa população trabalha. Entre os acolhidos em albergues, 17,9\% estão empregados com ou sem registro em carteiras e 57,7\% atuam por conta própria, em geral no comércio de rua ou na catação de lixo e fazendo bicos". (VILARDAGA, 2017).

7 Audiência conjunta das comissões de Assuntos Sociais (CAS) e de Assuntos Econômicos (CAE), em 10, de maio de 2017 (AGÊNCIA SENADO).

8 Segundo a Forbes, Jorge Paulo Lemann (AB Inbev), Joseph Safra (Banco Safra), Marcel Hermmann Telles (AB Inbev), Carlos Alberto Sicupira (AB Inbev), Eduardo Saverin (Facebook) e Ermirio Pereira de Moraes (Grupo Votorantim) têm, juntos, uma fortuna acumulada de 88,8 bilhões de dólares, equivalente a 277 bilhões de reais atualmente [...]. Para a diretora da Oxfam Brasil, essa situação é inadmissível e precisa ser enfrentada por todos para que realmente seja solucionada. "Existe uma distância absurda entre a maior parte da população brasileira e o $1 \%$ mais rico, não apenas em relação à renda e riqueza, mas também em relação ao acesso a serviços básicos como saúde e educação. Atacar essa questão é responsabilidade de todos", afirma. (SEIS..., 2017).

9 Paráfrase de trecho extraído do poema Cantares, de autoria do poeta espanhol Antônio Machado.

\section{Edvânia Ângela de Souza}

edvaniaangela@hotmail.com

Doutora em Serviço Social Universidade Estadual Paulista (UNESP)

Professora do Departamento de Serviço Social da Universidade Estadual Paulista (UNESP)

\section{UNESP}

Faculdade de Ciências Humanas e Sociais (FHCS) - UNESP- Franca, SP. 
Av. Eufrázia Monteiro Petráglia, 900

CEP: $14.409-160$

Franca-SP.

\section{Agradecimentos}

Agradecimento especial à Profa. Dra. Margarida Barreto, pela cordialidade que atendeu ao nosso convite e pela generosidade participando da entrevista e, logo após, de uma Mesa de debates. Agradecemos também os alunola(s) do grupo de estudos e pesquisas: "Mundo do Trabalho, Saúde do Trabalhador e Serviço Social” (GEMTSSS), em especial, a Rafael P. S. Alves responsável pela filmagem da entrevista com a Dra. Margarida Barreto.

Agência financiadora

Não se aplica

\section{Contribuições dos autores}

Não se aplica.

Aprovação por Comitê de Ética e consentimento para participação

Não se aplica.

Consentimento para publicação

Não se aplica.

\section{Conflito de interesses}

Não há conflito de interesses. 